\title{
CAR-T Cell Therapy: A Door Is Open to Find Innumerable Possibilities of Treatments for Cancer Patients
}

\author{
CAR-T Hücre Tedavisi: Kanser Hastalarına Sayııız Tedavi Olanağı Bulunması için Kapı Aralandı
}

\author{
(D) Lorena Perez-Amill1, (D) Berta Marzal2, (D) Alvaro Urbano-Ispizua1,3, (D) Manel Juan², (D) Beatriz Martín-Antonio1,3
}

1Institut d'Investigacions Biomèdiques August Pi i Sunyer Hospital, Clinic of Hematology, Barcelona, Spain

2 Institut d'Investigacions Biomèdiques August Pi i Sunyer Hospital, Clinic of Immunology, Barcelona, Spain

3Josep Carreras Leukaemia Research Institute, Barcelona, Spain

Lorena Perez-Amill and Berta Marzal contributed to this article equally.

\section{Abstract}

Seven years ago a chronic lymphocytic leukemia patient was for the first time successfully treated with chimeric antigen receptor (CAR)-modified T cells (CAR-T cells) to target CD19 overexpression in tumor cells. This was the beginning of the development of a new type of immunotherapy treatment in cancer patients. Since then, identification of novel antigens expressed in tumor cells and optimization of both CAR constructs and protocols of administration have opened up new avenues for the successful treatment of other hematological malignancies. However, research still continues to avoid some problems such as toxicities associated with the treatment and to find strategies to avoid tumor cell immune evasion mechanisms. On the other hand, for solid tumors, CAR-T therapy results are still in an early phase. In contrast to hematological malignancies, the complex tumor heterogeneity of solid tumors has led to the research of novel and challenging strategies to improve CAR-T cell activity. Here, we will review the main clinical results obtained with CAR-T cells in hematological malignancies, specifically focusing on CAR-T-19 and CAR-T against B-cell maturation antigen (CAR-T-BCMA). Moreover, we will mention the main problems that decrease CAR-T cell activity in solid tumors and the strategies to overcome them. Finally, we will present some of the first clinical results obtained for solid tumors.

Keywords: CAR-T cell immunotherapy, CD19, BCMA, GD2, HER2, EGFRvIll

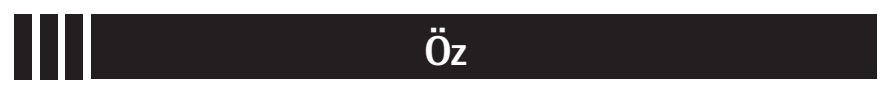

Yedi sene önce kronik lenfositik lösemili bir hasta ilk kez başarılı olarak tümör hücrelerinde aşırı sunulan CD19'u hedefleyen kimerik antijen reseptör (CAR)-ile değiştirilmiş $T$ hücreleri (CAR-T hücreleri) ile tedavi edilmiştir. Bu kanser hastalarında yeni bir tip immünoterapinin gelişiminin başlangıcını oluşturmaktaydı. Bunu takiben, tümör hücrelerinde sunulan yeni antijenlerin tanımlanması ve CAR yapılarını ve uygulama protokolleri diğer hematolojik habis tümörlerin başarılı tedavisi için yeni yollar açmıştır. Ancak, tedavi ile ilişkili toksisite gibi bazı problemlerin önlenmesi ve tümör hücresinin immün kaçış mekanizmalarıyla baş edilmesi ile ilgili çalışmalar halen devam etmektedir. Ayrıca, solid tümörler için, CAR-T tedavi sonuçları halen erken dönemdedir. Hematolojik habis tümörlerin aksine, solid tümörlerin karmaşık tümör heterojenitesi CAR-T hücre aktivitesi arttırmaya yönelik yeni ve zorlayıcı stratejilerinin araştırılmasına yol açmıştır. Burada, CAR-T hücrelerinin hematolojik habis tümörlerdeki, özellikle de CAR-T-19 ve B-hücre matürasyon antijenine karşı CAR-T'nin (CAR-T-BCMA) başlıca klinik sonuçlarını gözden geçireceğiz. Ayrıca, solid tümörlerde CAR-T hücre aktivitesini azaltan problemlerden ve bunların üstesinden gelmeye yarayan stratejilerden bahsedeceğiz. Son olarak, solid tümörlerdeki ilk klinik çalışmaların bazılarını sunacağız.

Anahtar Sözcükler: CAR-T hücre immünoterapisi, CD19, BCMA, GD2, HER2, EGFRvIII

\section{Introduction: Chimeric Antigen Receptor-T Cell Therapy}

The last decade has witnessed a huge increase in new immunotherapy modalities to treat cancer patients, such as the infusion of chimeric antigen receptor (CAR) modified-T cells (CAR-T cells), which represents the most important advance made to treat hematological malignancies in patients with relapsed/ refractory $(r / r)$ disease. CARs are composed of different synthetic domains combined into a single functional receptor that provides antigen-binding to an antigen present on the tumor cell and T-cell activation after antigen recognition [1]. Once a specific CAR has been designed, CAR-T cell therapy consists on the ex vivo modification of autologous $T$ cells from the patient to express this CAR on their membranes. Afterwards, CAR-T cells are expanded in vitro for 8-10 days and reinfused into the patient, where they will recognize and kill the tumor cells.

๑Copyright 2018 by Turkish Society of Hematology

Turkish Journal of Hematology, Published by Galenos Publishing House

口.

Received/Geliş tarihi: June 06, 2018 August Pi i Sunyer Hospital, Clinic of Hematology, Barcelona, Spain

Phone : +34 610980307

E-mail : bmartina@clinic.ub.es ORCID-ID: orcid.org/0000-0003-0674-4660 
A CAR is composed of three domains: 1) The extracellular region codes for the single-chain variable fragment (scFv) of an antibody against the antigen present in the tumor cell. In this region, there is a spacer/hinge domain derived from CD8 and from immunoglobulin $\mathrm{G}(\mathrm{lgG})$ sequences that profoundly affects CAR function and scFv flexibility [2]. 2) The CAR transmembrane domain, derived from T-cell molecules, such as $\mathrm{CD} 3 \zeta$, $C D 4, \mathrm{CD} 8 \mathrm{a}$, or $\mathrm{CD} 28$, links the extracellular domain with 3) the intracellular domain, which activates the T cells and is composed of CD3 $\zeta$ T-cell receptor. This is the structure of the first-generation CAR-T cells, which have the benefit of not requiring antigen processing/presentation by the human leukocyte antigen (HLA), allowing them to bypass HLA-I restriction $[3,4]$.

For the first-generation CAR-T cells, it was observed that even when the CAR-T cell mechanism was active, T cells did not proliferate in vivo, and moreover, a robust cytokine response after recognition of a tumor cell was not observed. This finding led to the addition of costimulatory domains in the CAR construct, giving rise to second- and third-generations CAR-T cells. Initially, CD28 was selected as the costimulatory domain by Savoldo et al. [5], who compared two autologous CAR-T types with the same specificity for CD19, one that encoded $\mathrm{CD} 3 \zeta$ and $C D 28$, while the other encoded only CD3 $\zeta$. The CAR-T cells containing CD28 showed enhanced expansion and persistence, confirming the requirement of costimulatory domains in the CAR construct. At the same time, Porter et al. [6] observed that the inclusion of 4-1BB as a costimulatory domain increased the antitumor activity and the in vivo persistence of CAR-T cells compared to CAR-T cells with the $\mathrm{CD} 3-\zeta$ domain alone. Therefore, costimulatory domains such as $\mathrm{CD} 28,4-1 \mathrm{BB}$, and $\mathrm{OX} 40[7,8,9]$ were included in second-generation CAR-T cells, providing higher in vivo CAR-T cell proliferation than first-generation CAR-T cells. It was observed that whereas CD28 is better to activate T cells, 4-1BB increases CAR-T cell persistence [10]. Therefore, the majority of recent clinical studies on hematological malignancies are infusing CAR-T cells with 4-1BB. Moreover, third- and fourth-generations of CAR constructs have also been added to the CAR-T arsenal. Third-generation CAR-T cells encode more than one costimulatory domain to enhance T-cell activation and proliferation. Fourth-generation CAR-T cells, also known as TRUCKs or "armored CARs", incorporate a constitutive or inducible expression domain for a protein that needs to be induced or constitutively secreted. Therefore, these CARs can deliver a product to the targeted tumor tissue (i.e. a cytokine), but they also could incorporate a peptide to recognize and bind to its ligand (i.e. CD40L) in the target cell, and to interact with other immune cells such as dendritic cells (i.e. 4-1BBL) (Figure 1) [11,12].

\section{Cytokine Release Syndrome Associated with CAR-T Cells}

The most common toxicity associated with CAR-T cell therapy is a massive inflammatory response called cytokine release syndrome (CRS), which results from high cytokine levels released after T-cell engagement and proliferation. In most patients, CRS occurs 1-14 days after CAR-T cell infusion. Most patients develop low-grade CRS with fevers and myalgias. However, some patients experience severe CRS with hypotension, pulmonary edema, coagulopathy, vascular leak, and neurotoxicity in some cases, which can result in multiorgan system failure [13]. Interleukin (IL)-6 is a central mediator of CRS and CRS is well managed with tocilizumab, an anti-IL-6 receptor. However, corticosteroids have also been successfully used without compromising CAR-T cell proliferation or efficacy $[14,15]$. Managing CRS requires performing appropriate grading to define its onset and grading and resolution criteria. Currently, there are three CRS grading scales. The first scale used to define CRS is the one graded by the National Cancer Institute, called the Common Terminology Criteria for Adverse Events; however, this system was not specific for cellular therapeutic approaches. Afterwards, Lee et al. [16] proposed a specific scale for cellular therapeutic modalities, which was slightly modified by the MD Anderson Cancer Center proposing a new grading system [17]. Currently, the most widely used scale is the one proposed by the University of Pennsylvania (UPenn), based on the clinical results of their murine CAR-T-19 (tisagenlecleucel) after treatment of 125 patients with B-cell acute lymphoblastic leukemia (B-ALL) and 42 patients with chronic lymphocytic lymphoma (CLL). This scale is based on easily accessible clinical features and not laboratory values, which makes it possible for it to be applied more widely by

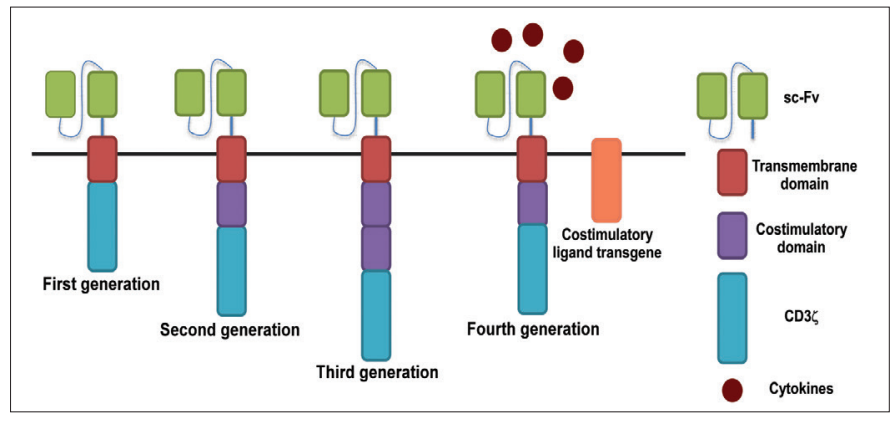

Figure 1. Structure of different chimeric antigen receptor (CAR) generations. First-generation CARs contain the singlechain variable fragment bound to the spacer/hinge domain, a transmembrane domain region with CD8 being the most commonly used, and the T-cell receptor CD3z domain. Secondgeneration CARs add one costimulatory domain to the construct, and third-generation CARs contain more than one costimulatory domain. Fourth-generation CARs contain an inducible or constitutive domain for another protein such as cytokines or specific ligand receptors.

scFv: Single-chain variable fragment. 
many hospitals. It applies to both early-onset and delayedonset CRS, and it distinguishes between mild, moderate, severe, and life-threatening CRS [18]. This scale was used in two multicenter phase II trials infusing tisagenlecleucel in $r / r$ ALL patients performed in 11 different countries and nine sites in the United States. At all of these centers, using this scale, $81 \%$ of the patients experienced some grade of CRS and $45 \%$ suffered grade 3 or 4 CRS $[18,19]$. In addition, this scale has also been adopted for other CAR constructs against B-cell maturation antigen (BCMA) for multiple myeloma (MM) [20] and against mesothelin in epithelial ovarian cancer [21]. Table 1 summarizes the grading and CRS management adopted by our institution.

\section{From the Initial Stages Infusing CAR-T-19 to a High CAR-T Cell} Variety to Treat Different Malignancies

More than 20 years have passed from the first studies with first-generation CAR-T cells $[22,23]$ to the design of secondgeneration CAR-T cells and finally the first successful clinical study in 2011 to treat a CLL patient with CAR-T-19 cells achieving complete remission (CR) [6]. Since then, an increasing number of clinical studies started to be performed, and today almost 200 clinical trials infusing CAR-T cells are being performed around the world. The greatest results have been obtained with CAR-T-19 in B-cell malignancies. Here, we will review some of the most relevant results obtained with CAR-T-19 and CAR-T-BCMA to treat MM. Moreover, we

Table 1. Grading of cytokine release syndrome and management of complications performed at our institution (Hospital Clinic of Barcelona) based on the grading scales of Lee et al. [16] and UPenn Porter et al. [18] and management recommendations.

\begin{tabular}{|c|c|c|}
\hline Grade & Symptoms & Treatment \\
\hline Grade 1 & $\begin{array}{l}\text { Not life-threatening symptoms: fever, } \\
\text { nausea, fatigue, headache, myalgia, malaise }\end{array}$ & $\begin{array}{l}\text { Conventional treatment to decrease temperature (paracetamol, ibuprofen, } \\
\text { naproxen) } \\
\text { Maintenance by intravenous fluids for hydration } \\
\text { Antibiotics in case of infection } \\
\text { Avoid immunosuppressors and steroids }\end{array}$ \\
\hline Grade 2 & $\begin{array}{l}\text { Symptoms require moderate intervention: } \\
\text { oxygen requirement }<40 \% \text { or hypotension } \\
\text { responsive to fluids or low dose of a } \\
\text { vasopressor or Grade } 2 \text { organ toxicity }\end{array}$ & $\begin{array}{l}\text { For nonadvanced age and/or without comorbidity: } \\
\text { Assess management in intermediate care } \\
\text { Manage fever and constitutional symptoms as in Grade } 1 \\
\text { Fluid bolus to maintain systolic blood pressure at }>90 \mathrm{mmHg} \\
\text { Supplementary } \mathrm{O}_{2} \text { to maintain } \mathrm{O}_{2} \mathrm{sp} \text { at }>90 \% \\
\text { Obtain echocardiogram and initiate methods of hemodynamic monitoring } \\
\text { For patients with high risk, consider tocilizumab } \\
\text { For advanced age and/or cardiorespiratory comorbidity: } \\
\text { Assess management in intermediate care } \\
\text { Manage fever and constitutional symptoms as in Grade I } \\
\text { Fluid bolus and low noradrenalin doses } \\
\text { Supplementary } \mathrm{O}_{2} \text { to maintain } \mathrm{O}_{2} \mathrm{sp} \text { at }>90 \% \\
\text { Assess tocilizumab administration }\end{array}$ \\
\hline Grade 3 & $\begin{array}{l}\text { Symptoms require severe intervention: } \\
\text { oxygen requirement }>40 \% \text { or hypotension } \\
\text { requiring high-dose or multiple vasopressors } \\
\text { or Grade } 3 \text { organ toxicity }\end{array}$ & $\begin{array}{l}\text { Management in an intensive care unit } \\
\text { Management as in Grade } 2 \\
\text { Supplementary } \mathrm{O}_{2} \text { to maintain } \mathrm{O}_{2} \mathrm{sp} \text { at }>90 \% \\
\text { Intravenous fluid bolus as needed } \\
\text { High doses of vasopressors or multiple vasopressors } \\
\text { Tocilizumab } \pm \text { steroids }\end{array}$ \\
\hline Grade 4 & $\begin{array}{l}\text { Life-threatening symptoms: requirement for } \\
\text { ventilator support or Grade } 4 \text { organ toxicity }\end{array}$ & $\begin{array}{l}\text { Management in an intensive care unit } \\
\text { Management as in Grade } 3 \\
\text { Mechanical ventilation } \\
\text { Tocilizumab } \pm \text { steroids }\end{array}$ \\
\hline
\end{tabular}


will mention other CAR constructs employed to treat B-cell malignancies not responding to CAR-T-19.

\section{CAR-T-19 for the Treatment of B-Cell Malignancies}

Three different institutions, the National Cancer Institute $(\mathrm{NCl})$, UPenn, and the Memorial Sloan-Kettering Cancer Center (MSKCC), have been the pioneering centers performing clinical studies infusing second-generation CAR-T-19 cells to treat $\mathrm{ALL}, \mathrm{CLL}$, and lymphoma patients. Whereas the $\mathrm{NCl}$ and MSKCC have employed CAR-T-19 with CD28 as a costimulatory domain, UPenn selected 4-1BB. Their results have contributed to defining critical parameters including the best costimulatory domain, viral vector, gene transfer method, T-cell stimuli used during T-cell production, conditioning chemotherapy, and T-cell dose [24]. For instance, direct comparison by the MSKCC of CAR-T-19 with and without conditioning chemotherapy showed increased T-cell persistence and improved outcome with conditioning chemotherapy [25]. Regarding T-cell dose, whereas for CAR-T-19 this parameter is not so relevant [24], for other CAR constructs, such as BCMA in MM, a minimal CAR-T cell dose is required to achieve response [26]. In more detail, we will describe some clinical results obtained with CAR-T-19 to treat B-cell malignancies.

The first treated CLL patient received $1.46 \times 10^{5}$ CAR-T-19 cells/ $\mathrm{kg}$ split into three doses. CAR-T cells persisted for 6 months and remission was ongoing for 10 months. Because of this low CAR-T cell dose, CRS was reported 14 days after the first infusion, coinciding with peak levels of CAR-T-19 in peripheral blood (PB) [6]. Afterwards, two pediatric $r / r$ ALL patients were treated with CAR-T-19. The first patient received $1.2 \times 10^{7}$ CAR-T-19 cells $/ \mathrm{kg}$ for three consecutive days without lymphodepletion. Patient 2 received $1.4 \times 10^{6}$ CAR-T- 19 cells $/ \mathrm{kg}$ in a single dose and etoposide-cyclophosphamide was administered the week before. In both patients, expansion of CAR-T-19 was detected, and $\mathrm{CR}$ occurred the first month. However, whereas patient 1 had ongoing CR for 11 months, patient 2 had a CD19-negative relapse 2 months after treatment [14]. This was the first study describing CD19-negative relapses, one of the main problems after CAR-T-19 immunotherapy, which occurs in 78\% of relapsed patients [27]. This year updated results on 75 children and young adults receiving CAR-T-19 (tisagenlecleucel) to treat ALL have shown overall response (OR) of $81 \%$ within 3 months, including $60 \%$ CR. CRS occurred in $77 \%$ of patients [27]. These results provided the basis for the approval of the first gene therapy product in the United States in 2017, tisagenlecleucel, commercialized by Novartis to treat B-cell precursor ALL patients up to 25 years old [28].

Recently, the MSKCC published results for CAR-T-19 with CD28 in 53 adult $r / r$ ALL patients. At 29 months 83\% CR was obtained, while median disease-free survival (DFS) and overall survival (OS) were 6.1 and 12.9 months, respectively. Severe CRS occurred in 26\% of patients. Patients with low disease burden showed higher remission rates with 20.1 and 10.6 months of OS and DFS, respectively, and lower CRS than patients with higher disease burden [29].

Whereas results in ALL have been remarkable, in CLL and lymphoma cases the clinical results have been poorer. Comparison of 14 phase I clinical trials between 1991 and 2014 including 119 patients demonstrated that the OR rate was $73 \%$, with $93 \%$ of responses in ALL patients, followed by CLL with $62 \%$ and lymphoma patients with $36 \%$. Moreover, lymphodepletion, higher CAR-T cell dose, and no interleukin (IL)-2 administration were associated with better responses [30]. Interestingly, a more recent study of 24 CLL patients showed that CAR-T-19 is highly effective in high-risk CLL relapsed patients after ibrutinib treatment, showing $\mathrm{OR}$ of $71 \%$ and $83 \%$ CRS [31].

The CAR-T-19 from UPenn was used in 28 patients with $r / r$ diffuse large B-cell lymphoma (DLBCL) or follicular lymphoma with CAR-T cell doses from $1 \times 10^{8}$ to $5 \times 10^{8}$. CRS occurred in $18 \%$ of patients while $90 \%$ CR was obtained after 1 month. The CR rate at 3 months was $43 \%$ and $71 \%$ in DLBCL and follicular lymphoma patients, respectively. At 28.6 months, sustained remissions were maintained in $86 \%$ of DLBCL and in $89 \%$ of follicular lymphoma patients [32].

On the other hand, the CAR-T-19 from the NCl with CD28 was employed in a phase I study of 7 patients with $r / r$ DLBCL. Patients received $2 \times 10^{6}$ CAR-T-19 cells/kg. One patient (14\%) experienced grade 4 CRS. Grade $\geq 3$ CRS and neurotoxicity were observed in $14 \%$ and $57 \%$ of patients, respectively. OR and CR were $71 \%$ and $57 \%$, respectively. At 12 months, $43 \%$ of patients remained in CR [33]. Based on these results, a multicenter phase 2 study was performed to treat $101 \mathrm{r} / \mathrm{r}$ patients with DLBCL, primary mediastinal B-cell lymphoma, or transformed follicular lymphoma. Patients received $2 \times 10^{6}$ CAR-T-19 cells $/ \mathrm{kg}$. Grade 3 or higher CRS and neurologic events occurred in 13\% and $28 \%$ of the patients, respectively. OR was $82 \%$ and CR was $54 \%$. At 15.4 months, $42 \%$ of the patients continued having a response, with a $40 \%$ rate of CR. OS at 18 months was $52 \%$. Of the patients who showed disease progression, 27\% of them showed CD19-negative disease [34]. Based on these results, the Food and Drug Administration approved the first CAR-T-19 cell product, called axicabtagene ciloleucel (Yescarta, Kite Pharma), to treat $D L B C L$, primary mediastinal large B-cell lymphoma, and high-grade B-cell lymphoma [35].

\section{Other CAR Constructs Employed to Treat B-Cell Malignancies Not Responding to CAR-T-19}

Other CAR constructs, such as CAR-T cells against CD30 (CAR-T-30), have been used to treat to treat Hodgkin lymphoma $(\mathrm{HL})$ and anaplastic large cell lymphoma (ALCL), which do not 
express CD19. Recently, the induction of CR in $9 \mathrm{r} / \mathrm{r}$ patients with HL (7 patients) and ALCL (2 patients) even in the absence of a conditioning regimen was reported without CAR-related toxicities. Patients received from $0.2 \times 10^{8}$ to $2 \times 10^{8}$ of CAR-T-30 cells $/ \mathrm{m}^{2}$. Seven of 9 patients received two or more infusions of CAR-T-30. Fourteen percent of HL patients entered CR lasting more than 2.5 years after the second infusion, 14\% remained in CR for almost 2 years, and $43 \%$ had transient stable disease. For ALCL, one patient had CR for 9 months after the fourth infusion of CAR-T cells. Interestingly, although CD30 may be expressed by normal activated T cells, no patients developed impaired virus-specific immunity [36]. Tables 2 and 3 summarize additional studies of other targets.

\section{CAR-T-BCMA for MM and Other B-Cell Malignancies}

BCMA has appeared as a promising target to treat MM patients due to specific BCMA expression in plasma cells and its absence in most tissues [37]. Currently, more than 20 clinical trials are infusing CAR-T-BCMA for MM treatment. Due to the restricted BCMA expression pattern, BCMA was defined as the most suitable antigen to treat $M M$, and the design of novel and effective CAR-T-BCMA with CD28 [38] opened the path for a clinical trial in MM patients in 2016. This study infused CAR-T-BCMA in $12 \mathrm{r} / \mathrm{r}$ MM patients. Patients received different CAR-T-BCMA cell doses $\left(0.33 \times 10^{6}, 1 \times 10^{6}, 3 \times 10^{6}\right.$, and $9 \times 10^{6}$ CAR-T-BCMA cells $/ \mathrm{kg}$ ). The 2 lowest doses achieved limited responses. At the third dose, a partial loss of BCMA expression in MM cells was detected in one patient, and one patient (25\%) obtained very good partial response (VGPR). At the highest dose, one patient (50\%) achieved CR for 17 weeks before relapse, and the other patient showed VGPR for 28 weeks. Both patients developed CRS [26]. These results were extended to perform a multicenter study to treat 21 patients in a dose-escalation study. CD28 was changed by $4-1 B B$ and the CAR-T-BCMA was now called bb2121. It was found that $71 \%$ of patients developed CRS. The lowest dose $\left(50 \times 10^{6}\right.$ cells) infused in three patients was not active. The other 18 patients receiving $150 \times 10^{6}$ ( 6 patients), $450 \times 10^{6}$ (9 patients), and $800 \times 10^{6}$ cells ( 3 patients) showed 94\% OR, 89\% VGPR, and $56 \%$ CR. Durable responses were ongoing over 1 year, and more importantly, responses continued to improve over time from VGPR to CR [39].

Additional studies with CAR-T-BCMA have been also successful. Cohen et al. [40] treated $21 \mathrm{r} / \mathrm{r}$ MM patients with CAR-T-BCMA in split-doses (10\% on day $0,30 \%$ on day 1 , and $60 \%$ on day 2). Patients were assigned to three cohorts: $1-5 \times 10^{8}$ CAR-T cells (cohort 1: 9 patients), cyclophosphamide (CXT) $1.5 \mathrm{~g} / \mathrm{m}^{2}$ $+1-5 \times 10^{7}$ CAR-T cells (cohort 2: 5 patients), and CTX $1.5 \mathrm{~g} / \mathrm{m}^{2}$ $+1-5 \times 10^{8}$ CAR-T cells (cohort 3: 7 patients). Cohort 1 showed the highest CRS at 89\% and 1 patient had ongoing CR at 21 months. Cohorts 2 and 3 showed 75\% CRS. Cohort 2, with the lowest CAR-T dose, showed the lowest response (40\%), which progressed at 4 and 2 months. Cohort 3, with a high CAR-T dose, at 1 month of follow-up showed $83 \%$ of any type of response. Interestingly, in $83 \%$ of the patients with $\geq P R$, MM cells showed decreased BCMA intensity [40]. More recently, a human CAR-T-BCMA was developed at the MSKCC, which hopefully will avoid early disappearance of CAR-T cells. Clinical results with this human CAR construct were recently published [41]. At our institution (Hospital Clinic), we have designed a highly effective CAR-T-BCMA. Moreover, we have also humanized the scFv, confirming its high efficacy, and in the next few months it will be used in a multicenter phase I study to treat $r / r$ MM patients.

Moreover, Friedman et al. [42], who designed the CAR-T-BCMA (bb2121) [26], identified BCMA expression in primary lymphoma and CLL cells and confirmed the high efficacy of CAR-T-BCMA against models of MM, Burkitt lymphoma, and mantle cell lymphoma, suggesting that this CAR construct could be also efficient for these malignancies.

One of the problems observed in CAR-T immunotherapy for $\mathrm{MM}$ is the proportion of relapsed patients no longer having BCMA expression. Different options to avoid this, such as the use of dual CAR constructs targeting two different antigens, are being tested. Lee et al. [16] confirmed that $100 \%$ of primary MM cells expressed BCMA, and 78\% of them also expressed TACl. Therefore, they successfully tested a third-generation dual CAR-T-APRIL (a ligand for BCMA and TACI), which eliminated MM cells expressing either BCMA or TACl and demonstrated tumor control in the absence of BCMA [43].

The impressive results in $r / r$ MM patients targeting BCMA [39] suggest that after CAR-T-19, BCMA will be the next area where CAR-T therapy will have a high clinical impact. However, some problems still need to be addressed, such as the high CAR-T cell dose required to achieve responses, which could cause high CRS rates. New clinical protocols will aim to ameliorate severe CRS. Interestingly, for other CAR constructs such as CAR-T-20, Watanabe et al. [44] observed that the threshold of antigen density in the tumor required to induce CAR-T cell lytic activity was around 200 molecules per target cell, and for cytokine production it was 10-fold higher, suggesting a range for antigen density in the tumor cell where cytotoxicity can be performed without development of CRS. Second, the loss of BCMA expression in MM cells after CAR-T-BCMA treatment is a problem. Different strategies, such as dual CAR constructs, are being tested. Third, early disappearance of CAR-T cells in patients may be solved with the use of human and humanized CARs.

\section{Homemade CARs: A Reality?}

As previously mentioned, CAR-T-19 cell products have been commercialized by pharmaceutical companies, with prices of 


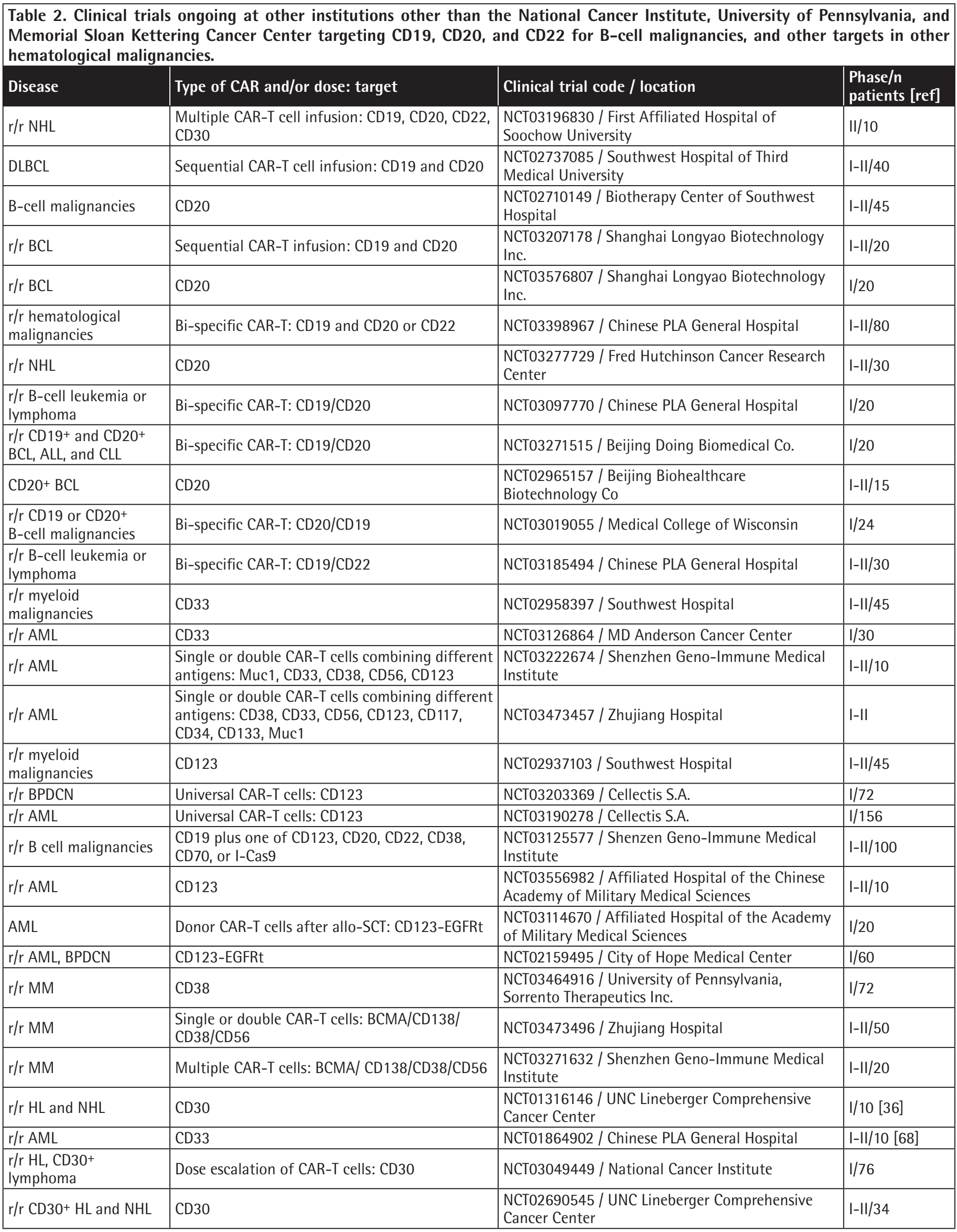


$\$ 475,000$ for tisagenlecleucel and $\$ 373,000$ for Yescarta. If the positive results obtained continue this trend, hopefully CAR-T-BCMA will also be approved for use in MM patients. Unfortunately, these prices are not affordable for many public national health systems. In this sense, at our institution, we have manufactured our CAR-T-19 cell product. This process requires having a good manufacturing practice facility to perform the viral production. Afterwards, the T-cell transfection is performed in the Prodigy device (Miltenyi, Biotec), a sterile isolated system, which performs all the steps required, starting from the apheresis product to the final product of CAR-T cells. This option provides much more affordable prices that can be assumed by a public national health system. With these CAR-T-19 cells (called ARI0001), 18 patients with $r / r$ B-cell malignancies have already been treated and a phase II clinical trial is about to start.

\section{CAR-T Cells for the Treatment of Solid Tumors}

Contrary to hematological malignancies, severe side effects, lack of persistence and effectiveness of CAR-T cells, immunosuppression in the tumor microenvironment, lack of homing, and tumor-off/target-on effects occurring in solid tumors decrease the success of CAR-T therapy for these malignancies [45]. Some strategies employed to improve these problems include the following: 1) Fourth-generation CAR-T cells, by incorporating additional features, such as costimulatory ligands next to the CAR receptor and more than one costimulatory domain, improve the lack of persistence and efficacy of CAR-T cells. In this sense, combining CD28 with OX40 blocks IL-10 production, increasing persistence and conferring higher efficacy to the CAR-T cells $[45,46,47]$. Combination of CAR-T cells with oncolytic viruses has also been suggested to improve CAR-T efficacy [48]. 2) To overcome the immunosuppressive microenvironment, the preselection of virus-specific CTLs before CAR-T cell transduction achieves a double CAR-T stimulation, either by the TCR or by the CAR, appearing as an option to avoid loss of expression of the tumor antigen [49]. Another option being tested is the combination of CAR-T cells with immunocheckpoint inhibitors, which seems to improve the potency of CAR-T cells [47]. In addition, fourth-generation CAR-T cells can modulate

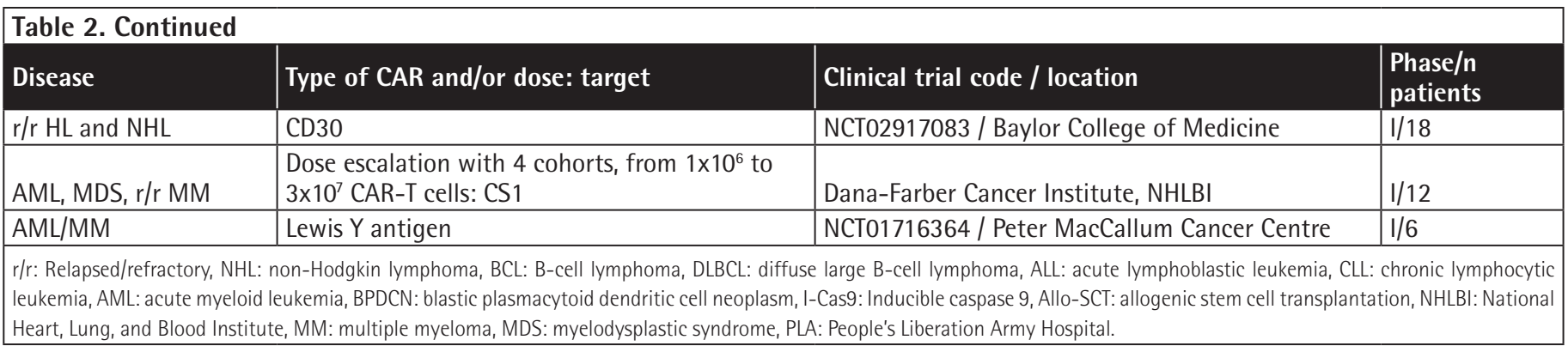

\begin{tabular}{|c|c|c|c|}
\hline Disease & Target / CAR-T cell dose & N patients / clinical outcome & Clinical trial code / location [ref] \\
\hline$r / r H L$ & $\begin{array}{l}\text { CD30 / On day 0: } 3.2 \times 10^{5} \text { CAR-T/kg; from } \\
\text { day } 3 \text { to } 5,5 \text {-fold increments }\end{array}$ & $18.39 \%$ PR, 33\% SD & $\begin{array}{l}\text { NCT02259556 / Chinese PLA General } \\
\text { Hospital [69] }\end{array}$ \\
\hline$r / r$ AML & $\begin{array}{l}\text { CD33 / } 1.12 \times 10^{9} \text { CAR-T cells; dose } \\
\text { escalation over } 4 \text { days }\left(1 \times 10^{8} \text { day } 1\right. \\
1.2 \times 10^{8} \text { day } 2,4 \times 10^{8} \text { day } 3 \text {, and } 5 \times 10^{8} \\
\text { day } 4)\end{array}$ & $\begin{array}{l}1 \text { / Grade IV toxicity, response at } 2 \text { weeks } \\
\text { with progression at } 9 \text { weeks }\end{array}$ & $\begin{array}{l}\text { NCT01864902 / Chinese PLA General } \\
\text { Hospital [70] }\end{array}$ \\
\hline $\begin{array}{l}\text { r/r CD20+ } \\
\mathrm{BCL}\end{array}$ & $\begin{array}{l}\text { CD20 / Escalating doses split into } 3-5 \\
\text { doses on consecutive days; total dose } \\
\text { from } 0.41 \times 10^{7} \text { to } 1.46 \times 10^{7} \text { cells/kg }\end{array}$ & $\begin{array}{l}11 / \text { OR } 81.8 \%, 6 \text { CR and } 3 \text { PR; no severe } \\
\text { toxicity observed; PFS >6 months, } 1 \text { patient } \\
C R>27 \text { months }\end{array}$ & $\begin{array}{l}\text { NCT01735604 / Chinese PLA General } \\
\text { Hospital [71] }\end{array}$ \\
\hline r/r AML & $\begin{array}{l}\text { Lewis } Y / 1.1 \times 10^{9} \mathrm{~T} \text { cells (ranging from } \\
5 \times 10^{8} \text { to } 1.3 \times 10^{9} \text { ) }\end{array}$ & $\begin{array}{l}5 \text { / III-IV grade toxicity not observed; } 1 \\
\text { patient with cytogenetic remission, } 1 \text { with } \\
\text { reduction in peripheral blood, } 1 \text { protracted } \\
\text { remission }\end{array}$ & $\begin{array}{l}\text { NCT01716364 / University of } \\
\text { Melbourne, Australia, Heidelberg- } \\
\text { Australia [72] }\end{array}$ \\
\hline $\begin{array}{l}\text { r/r B-cell } \\
\text { and mantle } \\
\text { lymphoma }\end{array}$ & $\begin{array}{l}\text { CD20 / } 3 \text { infusions of escalating doses of } \\
10^{8}, 10^{9} \text {, and } 3.3 \times 10^{9} \text { cells } / \mathrm{m}^{2}\end{array}$ & $\begin{array}{l}4 \text { / } 2 \text { patients with PFS of } 12 \text { and } 24 \\
\text { months; } 1 \text { patient in OR and relapsed after } \\
12 \text { months }\end{array}$ & $\begin{array}{l}\text { NCT00621452 / Fred Hutchinson } \\
\text { Cancer Research Center, Seattle, WA, } \\
\text { USA [73] }\end{array}$ \\
\hline $\begin{array}{l}r / r \mathrm{HL} \text { and } \\
\mathrm{ALCL}\end{array}$ & $\begin{array}{l}\text { CD30 / } 3 \text { doses from } 0.2 \times 10^{8} \text { to } 2 \times 10^{8} \\
\text { CAR-T cells } / \mathrm{m}^{2}\end{array}$ & $\begin{array}{l}9 \text { / No toxicities; } 7 \text { patients with } \mathrm{HL}, 1 \mathrm{CR} \\
>2.5 \text { years, } 1 \mathrm{CR}>2 \text { years, } 3 \text { transient } \mathrm{SD} ; \\
2 \text { patients with } \mathrm{ALCL}, 1 \mathrm{CR}>9 \text { months }\end{array}$ & $\begin{array}{l}\text { NCT01316146 / UNC Lineberger } \\
\text { Comprehensive Cancer Center [36] }\end{array}$ \\
\hline
\end{tabular}


the tumor environment through the secretion of IL-12 and can also increase tumor cell-CAR-T cell contact by the release of adhesion molecules or enzymes that degrade the extracellular matrix $[50,51]$. CRISPR/CAS9 technology appears as a further option to generate CAR-T cells resistant to exhaustion and inhibition [52]. 3) Moreover, the high tumor-off/targeton effect occurring in solid tumors can be ameliorated by variations in the administration route for CAR-T cells, cell dose, reduction of scFv affinity, use of "switchable CARs", and the discovery of specific tumor-associated antigens $[45,53]$. Additional proposals for CAR construct design include the insertion of caspase 9 into the CAR construct, which after administration of a small molecule (AP1903) to the patient will induce apoptosis of $99 \%$ of CAR-T cells [54]. Inducible caspase 9 is already being used in clinics, demonstrated to be safe (Table 4). Moreover, the design of transient CAR-T cells by introducing CAR-T mRNA by electroporation has shown antitumor activity in CAR-T-19 for CLL patients [55] and CART-mesothelin for solid tumors [56], and it is being employed in clinical trials (Table 4). Due to all these limitations, positive clinical results with CAR-T cells in solid tumors are scarce, most of them in phase I trials. We will now mention some of the most interesting results obtained with CAR-T cells in solid tumors.

Specific disialoganglioside 2 (GD2) expression in tumor cells and slight expression in normal cells [57] makes GD2 a good candidate for CAR-T therapy, specifically for neuroblastoma. Eight neuroblastoma patients receiving Epstein-Barr virus (EBV)virus-specific CTLs with CAR-T-GD2 showed evidence of tumor necrosis and one patient remained in $C R$, suggesting that virus- specific CTLs expressing CAR-T-GD2 show higher persistence in contrast to virus-nonspecific CAR-T cells [49].

Human epidermal growth factor receptor 2 (HER2) is not detected in normal brain tissues, being overexpressed in 25\%$30 \%$ of breast and ovarian cancers, $60 \%$ of osteosarcomas, $80 \%$ of glioblastoma multiforme (GBM) cases, and $40 \%$ of medulloblastomas [51]. Although HER2 has been successfully targeted with anti-HER2-antibodies (trastuzumab and pertuzumab) in HER2/neu2+ breast cancer, the first breast cancer patient treated with CAR-T-HER2 died because of severe toxicity related to tumor-off/target-on effect [58]. In contrast, gliomas, glioblastomas, GBM, and medulloblastomas showing lower levels of HER2 than breast cancer are not efficiently treated with trastuzumab. Therefore, $17 \mathrm{GBM}$ patients received from $10^{6}$ to $10^{8}$ cells $/ \mathrm{m}^{2}$ of intravenous polyclonal EBV-cytomegalovirus and adenovirus-specific $\mathrm{T}$ cells transduced with CAR-T-HER2 (CAR-T-FRP5). Median OS was 11 months, no serious side effects were reported, and CAR-T cells were detected in PB 12 months later [59].

IL-13 receptor alpha-2 (IL-13R $\alpha 2$ ) is overexpressed in 75\% of glioblastoma patients $[60,61,62]$. The first study in 3 glioblastoma patients receiving up to 12 local intracranial infusions of virus-specific CTL clones transduced with CAR-IL13R 22 (E13Y-zetakine CAR) showed minimal side effects and transient responses in 2 patients [63]. Afterwards, the CAR construct was modified to incorporate 4-1BB and a mutated IgG4-Fc linker to reduce tumor-off/target-on effect. At a dose of $2 \times 10^{6}$ these CAR-T cells were administrated by intracranial infusion to one glioblastoma patient, followed by five additional infusions of $10 \times 10^{6}$ CAR-T cells. Severe toxicities did not develop

\begin{tabular}{|c|c|c|c|}
\hline Location / NCT code & $\begin{array}{l}\text { Antigen (method employed for } \\
\text { temporary CAR-T expression) }\end{array}$ & Malignancy & Phase \\
\hline MSKCC / NCT02414269 & Mesothelin (iCasp9) & $\begin{array}{l}\text { Malignant pleural disease, mesothelioma, } \\
\text { metastases, LC, BC }\end{array}$ & I \\
\hline BCM / NCT01822652 & GD2 (iCasp9) & Neuroblastoma & I \\
\hline MSKCC / NCT02792114 & Mesothelin (iCasp9) & $\mathrm{BC}$, metastatic HER2-negative $\mathrm{BC}$ & I \\
\hline $\begin{array}{l}\text { Shenzhen Geno-Immune Medical Institute / } \\
\text { NCT02992210 }\end{array}$ & GD2 (iCasp9) & Solid tumor & $1 / 11$ \\
\hline NCl / NCT02107963 & GD2 (iCasp9) & Sarcoma, osteosarcoma, NB, melanoma & I \\
\hline BCM / NCT01822652 & GD2 (iCasp9) & NB & I \\
\hline Bambino Gesù Hospital / NCT03373097 & GD2 (iCasp9) & NB & $1 / 11$ \\
\hline BCM / NCT01953900 & GD2/NZV vaccine (iCasp9) & Sarcomas & I \\
\hline $\begin{array}{l}\text { Abramson Cancer Center of UPenn / } \\
\text { NCT01897415 }\end{array}$ & Mesothelin (mRNA) & PDA & 1 \\
\hline UPenn / NCT01837602 & cMet (mRNA) & $\mathrm{BC}$, triple negative $\mathrm{BC}$ & I \\
\hline UPenn / NCT03060356 & cMet (mRNA) & Melanoma, BC & 1 \\
\hline
\end{tabular}


and regression of intracranial and spinal tumors during 7.5 months was observed [64].

Most GBM patients overexpress the mutated epidermal growth factor receptor (EGFR) variant III (EGFRvIII), which is associated with tumor progression and poor prognosis [65]. Comparison of humanized second- and third-generation CAR-T cells with 4-1BB and/or CD28/4-1BB against EGFRvIII in vitro and in vivo demonstrated higher efficacy for the third-generation CAR-T cells. Moreover, a lower-affinity scFv was designed to minimize the tumor-off/target-on effects, and finally this CAR-T cell combined with temozolomide was the optimal strategy in a xenograft glioblastoma model [66]. Based on these results, UPenn conducted the first study with 10 newly diagnosed patients with recurrent GBM with residual disease infusing intravenous CAR-T-EGFRvIll cells. No evidence of off-tumor toxicity or CRS was observed. One patient had residual stable disease for over 18 months. All patients demonstrated transient expansion and trafficking of CAR-T cells to regions of active GBM. However, expression of inhibitory molecules and regulatory T-cell infiltration after CAR-T-EGFRvIII infusion was detected in the tumor environment [67]. Many other ongoing clinical studies targeting EGFRvIII, GD2, and HER2 are summarized in Table 5.

\section{Conclusion}

In summary, CAR-T immunotherapy has achieved remarkable results in the treatment of hematological malignancies, leading to the commercialization of CAR-T cells as pharmaceutical products. Despite positive results, problems such as loss of expression of the target antigen and CRS could be improved. In solid tumors, additional complications due to intratumoral cell heterogeneity cause low responses and high toxicities. Novel

\begin{tabular}{|c|c|c|c|}
\hline Location / NCT code & Antigen & Malignancy & Phase \\
\hline Zhujiang Hospital / NCT02765243 & GD2 & NB & II \\
\hline $\mathrm{NCl} / \mathrm{NCT} 02107963$ & GD2 & NB & I \\
\hline BCM / NCT03294954 & GD2 & NB & I \\
\hline Cancer Research UK / NCT02761915 & GD2 & NB & $\mathrm{R}$ \\
\hline Bambino Gesù Hospital / NCT03373097 & GD2 & NB & $\mathrm{R}$ \\
\hline Seattle Children's Hospital / NCT02311621 & CD171/EGFRt & NB, GNB & $\mathrm{R}$ \\
\hline Chinese PLA General Hospital, Beijing / NCT01935843 & HER2 & Advanced HER2-positive ST & $1 / 11$ \\
\hline $\begin{array}{l}\text { The Methodist Hospital; Center for Cell and Gene Therapy, } \\
\text { BCM / NCT02442297 }\end{array}$ & HER2 & GB & 1 \\
\hline $\begin{array}{l}\text { The Methodist Hospital; Center for Cell and Gene Therapy, } \\
\text { BCM; Texas Children's Hospital / NCT01109095 }\end{array}$ & HER2 & GBM & 1 \\
\hline Seattle Children's Hospital / NCT03500991 & HER2 & Pediatric CNST & I \\
\hline Fuda Cancer Hospital, Guangzhou / NCT02547961 & HER2 & $\mathrm{BC}$ & $1 / I 1$ \\
\hline Southwest Hospital, China / NCT02713984 & HER2 & $\mathrm{BC}, \mathrm{OC}, \mathrm{LC}, \mathrm{GC}$, colorectal, glioma, PC & $1 / 11$ \\
\hline Hospital of Harbin Medical University / NCT03267173 & HER2 & PC & I \\
\hline Xuanwu Hospital, Beijing / NCT03423992 & HER2 & Glioma & I \\
\hline City of Hope Medical Center / NCT03389230 & HER2/CD19t & GB, glioma & I \\
\hline BCM / NCT00902044 & HER2 & Sarcomas & I \\
\hline Duke University Medical Center / NCT02664363 & EGFRvIII & GB & I \\
\hline NCl / NCT01454596 & EGFRvIII & Glioma, GB, BC, gliosarcoma & $1 / 11$ \\
\hline Beijing Sanbo Brain Hospital / NCT02844062 & EGFRvIII & GBM & I \\
\hline NCl, Duke Cancer Institute / NCT03283631 & EGFRvIII & GBM & I \\
\hline Shenzhen Geno-Immune Medical Institute / NCT03170141 & EGFRvIII & GBM & $1 / 11$ \\
\hline Xuanwu Hospital, Beijing / NCT03423992 & EGFRvIII & Glioma & 1 \\
\hline $\mathrm{NCl} / \mathrm{NCT} 01454596$ & EGFRvIII & Glioma, GB, BC, gliosarcoma & $1 / 11$ \\
\hline Duke University Medical Center / NCT02664363 & EGFRvIII & GB & 1 \\
\hline UPenn, UCA / NCT02209376 & EGFRvIII & GB & I \\
\hline \multicolumn{4}{|c|}{$\begin{array}{l}\text { BCM: Baylor College of Medicine, NCI: National Cancer Institute, UPenn: University of Pennsylvania, UCA: University of California, R: recruitin, GB: glioblastoma, GBM: glioblastoma } \\
\text { multiforme, PC: pancreatic cancer, LC: lung cancer, BC: breast cancer, OC: ovarian cancer, GC: gastric cancer, BC: brain cancer, NB: neuroblastoma, GNB: ganglioneuroblastoma, ST: solid } \\
\text { tumors, CNST: central nervous system tumor, PLA: People's Liberation Army Hospital, GD2: disialoganglioside 2, HER2: human epidermal growth factor receptor 2, EGFRvIll: epidermal } \\
\text { growth factor receptor variant III. }\end{array}$} \\
\hline
\end{tabular}


CAR designs, modification of clinical protocols, discovery of novel tumor-specific antigens, and novel molecular strategies will improve clinical results for both hematological and solid tumors.

\section{Ethics}

Ethics Committee Approval: Hospital Clinic of Barcelona, approval number: HCB/2017/0438.

\section{Authorship Contributions}

Concept: L.P.A., B.M.; Design: L.P.A., B.M.; Literature Search: L.P.A., B.M.; Writing: L.P.A., B.M., B.M.A., M.J., A.U.I.

Conflict of Interest: The authors of this paper have no conflicts of interest, including specific financial interests, relationships, and/or affiliations relevant to the subject matter or materials included.

Financial Disclosure: Celgene and Institute of Health Carlos III (projects PI14/00798 and PI17/01043) provided funding for all studies.

\section{References}

1. Sadelain $M$, Brentjens $R$, Rivière $I$. The basic principles of chimeric antigen receptor design. Cancer Discov 2013;3:388-398.

2. Dai H, Wang Y, Lu X, Han W. Chimeric antigen receptors modified T-cells for cancer therapy. J Natl Cancer Inst 2016;108:djv439.

3. Chang ZL, Chen YY. CARs: Synthetic immunoreceptors for cancer therapy and beyond. Trends Mol Med 2017;23:430-450.

4. Hartmann J, Schüßler-Lenz M, Bondanza A, Buchholz CJ. Clinical development of CAR T cells-challenges and opportunities in translating innovative treatment concepts. EMBO Mol Med 2017;9:1183-1197.

5. Savoldo B, Ramos CA, Liu E, Mims MP, Keating MJ, Carrum G, Kamble RT, Bollard CM, Gee AP, Mei Z, Liu H, Grilley B, Rooney CM, Heslop HE, Brenner MK, Dotti G. CD28 costimulation improves expansion and persistence of chimeric antigen receptor-modified T cells in lymphoma patients. J Clin Invest 2011;121:1822-1826.

6. Porter DL, Levine BL, Kalos M, Bagg A, June CH. Chimeric antigen receptormodified T cells in chronic lymphoid leukemia. N Engl J Med 2011;365:725733.

7. Zhong XS, Matsushita M, Plotkin J, Riviere I, Sadelain M. Chimeric antigen receptors combining 4-1BB and $C D 28$ signaling domains augment $\mathrm{Pl}_{3}$ kinase/ $\mathrm{AKT} / \mathrm{Bcl}-\mathrm{XL}$ activation and $\mathrm{CD} 8^{+} \mathrm{T}$ cell-mediated tumor eradication. Mol Ther 2010;18:413-420.

8. Carpenito $C$, Milone $M C$, Hassan $R$, Simonet JC, Lakhal M, Suhoski MM, Varela-Rohena A, Haines KM, Heitjan DF, Albelda SM, Carroll RG, Riley JL, Pastan I, June CH. Control of large, established tumor xenografts with genetically retargeted human T cells containing CD28 and CD137 domains. Proc Natl Acad Sci U S A 2009;106:3360-3365.

9. Pule MA, Straathof KC, Dotti G, Heslop HE, Rooney CM, Brenner MK. A chimeric $T$ cell antigen receptor that augments cytokine release and supports clonal expansion of primary human T cells. Mol Ther 2005;12:933941.

10. Long $A H$, Haso WM, Shern JF, Wanhainen KM, Murgai $M$, Ingaramo $M$, Smith JP, Walker AJ, Kohler ME, Venkateshwara VR, Kaplan RN, Patterson GH, Fry TJ, Orentas RJ, Mackall CL. 4-1BB costimulation ameliorates T cell exhaustion induced by tonic signaling of chimeric antigen receptors. Nat Med 2015;21:581-590.
11. Chmielewski M, Abken H. TRUCKs: the fourth generation of CARs. Expert Opin Biol Ther 2015;15:1145-1154.

12. Yeku 00, Brentjens RJ. Armored CAR T-cells: utilizing cytokines and proinflammatory ligands to enhance CAR T-cell anti-tumour efficacy. Biochem Soc Trans 2016;44:412-418.

13. Maude SL, Barrett D, Teachey DT, Grupp SA. Managing cytokine release syndrome associated with novel T cell-engaging therapies. Cancer J 2014;20:119-122.

14. Grupp SA, Kalos M, Barrett D, Aplenc R, Porter DL, Rheingold SR, Teachey DT, Chew A, Hauck B, Wright JF, Milone MC, Levine BL, June CH. Chimeric antigen receptor-modified T cells for acute lymphoid leukemia. $N$ Engl J Med 2013;368:1509-1518.

15. Brentjens RJ, Davila ML, Riviere I, Park J, Wang X, Cowell LG, Bartido S, Stefanski J, Taylor C, Olszewska M, Borquez-Ojeda O, Qu J, Wasielewska T, He Q, Bernal Y, Rijo IV, Hedvat C, Kobos R, Curran K, Steinherz P, Jurcic J, Rosenblat T, Maslak P, Frattini M, Sadelain M. CD19-targeted T cells rapidly induce molecular remissions in adults with chemotherapy-refractory acute lymphoblastic leukemia. Sci Transl Med 2013;5:177-38.

16. Lee DW, Gardner R, Porter DL, Louis CU, Ahmed N, Jensen M, Grupp SA, Mackall CL. Current concepts in the diagnosis and management of cytokine release syndrome. Blood 2014;124:188-195.

17. Neelapu SS, Tummala S, Kebriaei P, Wierda W, Gutierrez C, Locke FL, Komanduri KV, Lin Y, Jain N, Daver N, Westin J, Gulbis AM, Loghin ME, de Groot JF, Adkins S, Davis SE, Rezvani K, Hwu P, Shpall EJ. Chimeric antigen receptor T-cell therapy - assessment and management of toxicities. Nat Rev Clin Oncol 2018;15:47-62.

18. Porter D, Frey N, Wood PA, Weng Y, Grupp SA. Grading of cytokine release syndrome associated with the CAR T cell therapy tisagenlecleucel. J Hematol Oncol 2018;11:35.

19. Maude SL, Grupp SA, Pulsipher MA, Rives R, Myers GD, Verneris MR, Buechner J, Laetsch TW, Bittencourt H, Boyer M, De Moerloose B, Qayed M, Davies S, Martin PL, Bader P, Schlis K, Wood P, Taran T, Zhang Y, Leung $\mathrm{M}$, June $\mathrm{CH}$, Levine J. Analysis of safety data from 2 multicenter trials of CTL019 in pediatric and young adult patients with relapsed/refractory (r/r) B-cell acute lymphoblastic leukemia (B-ALL). European Hematology Association 2017:P517.

20. Cohen AD, Garfall AL, Stadtmauer EA, Lacey SF, Lancaster E, Vogl DT, Dengel $K$, Ambrose DE, Chen F, Plesa G, Kulikovskaya I, Gonzalez VE, Gupta M, Young RM, Carey T, Ferthio R, Weiss BM, Richardson C, Isaacs RE, Melenhorst JJ, Levine BL, June $\mathrm{CH}$, Milone MC. B-cell maturation antigen (BCMA)-specific chimeric antigen receptor T cells (CART-BCMA) for multiple myeloma (MM): initial safety and efficacy from a phase I study. Blood 2016;128:1147.

21. Tanyi JL, Haas AR, Beatty GL, Stashwick CJ, O'Hara MH, Morgan MA, Porter $\mathrm{DL}$, Melenhorst JJ, Plesa G, Lacey SF, June CH. Anti-mesothelin chimeric antigen receptor T cells in patients with epithelial ovarian cancer. J Clin Oncol 2016;34:5511a (abstract).

22. Brocker T, Karjalainen K. Signals through T cell receptor-zeta chain alone are insufficient to prime resting T lymphocytes. J Exp Med 1995;181:1653-1659.

23. Gong MC, Latouche JB, Krause A, Heston WD, Bander NH, Sadelain M. Cancer patient $\mathrm{T}$ cells genetically targeted to prostate-specific membrane antigen specifically lyse prostate cancer cells and release cytokines in response to prostate-specific membrane antigen. Neoplasia 1999;1:123-127.

24. Davila ML, Brentjens R, Wang X, Riviere I, Sadelain M. How do CARs work?: Early insights from recent clinical studies targeting CD19. Oncoimmunology 2012;1:1577-1583.

25. Brentjens RJ, Rivière I, Park JH, Davila ML, Wang $X$, Stefanski J, Taylor C, Yeh R, Bartido S, Borquez-0jeda O, Olszewska M, Bernal Y, Pegram H, Przybylowski M, Hollyman D, Usachenko Y, Pirraglia D, Hosey J, Santos E, Halton E, Maslak P, Scheinberg D, Jurcic J, Heaney M, Heller G, Frattini M, Sadelain M. Safety and persistence of adoptively transferred autologous CD19-targeted T cells in patients with relapsed or chemotherapy refractory B-cell leukemias. Blood 2011;118:4817-4828. 
26. Ali SA, Shi V, Maric I, Wang M, Stroncek DF, Rose JJ, Brudno JN, StetlerStevenson M, Feldman SA, Hansen BG, Fellowes VS, Hakim F, Gress RE, Kochenderfer JN. T cells expressing an anti-B-cell maturation antigen chimeric antigen receptor cause remissions of multiple myeloma. Blood 2016;128:1688-1700.

27. Maude SL, Laetsch TW, Buechner J, Rives $S$, Boyer M, Bittencourt $H$, Bader $P$, Verneris MR, Stefanski HE, Myers GD, Qayed M, De Moerloose B, Hiramatsu $\mathrm{H}$, Schlis K, Davis KL, Martin PL, Nemecek ER, Yanik GA, Peters C, Baruchel A, Boissel N, Mechinaud F, Balduzzi A, Krueger J, June CH, Levine BL, Wood P, Taran T, Leung M, Mueller KT, Zhang Y, Sen K, Lebwohl D, Pulsipher MA, Grupp SA. Tisagenlecleucel in children and young adults with B-cell lymphoblastic leukemia. N Engl J Med 2018;378:439-448.

28. U.S. Food \& Drug Administration. Release FN. FDA Approval Brings First Gene Therapy to the United States. Washington, FDA, 2017.

29. Park JH, Rivière I, Gonen $M$, Wang $X$, Sénéchal $B$, Curran KJ, Sauter $C$, Wang Y, Santomasso B, Mead E, Roshal M, Maslak P, Davila M, Brentjens RJ, Sadelain M. Long-term follow-up of CD19 CAR therapy in acute lymphoblastic leukemia. N Engl J Med 2018;378:449-459.

30. Zhang T, Cao L, Xie J, Shi N, Zhang Z, Luo Z, Yue D, Zhang Z, Wang L, Han W, Xu Z, Chen H, Zhang Y. Efficiency of CD19 chimeric antigen receptormodified $T$ cells for treatment of B cell malignancies in phase I clinical trials: a meta-analysis. Oncotarget 2015;6:33961-33971.

31. Turtle CJ, Hay KA, Hanafi LA, Li D, Cherian S, Chen X, Wood B, Lozanski A, Byrd JC, Heimfeld S, Riddell SR, Maloney DG. Durable molecular remissions in chronic lymphocytic leukemia treated with CD19-specific chimeric antigen receptor-modified T Cells after failure of ibrutinib. J Clin Oncol 2017;35:3010-3020.

32. Schuster SJ, Svoboda J, Chong EA, Nasta SD, Mato AR, Anak Ö, Brogdon $\mathrm{JL}$, Pruteanu-Malinici I, Bhoj V, Landsburg D, Wasik M, Levine BL, Lacey $\mathrm{SF}$, Melenhorst JJ, Porter DL, June $\mathrm{CH}$. Chimeric antigen receptor T cells in refractory B-cell lymphomas. N Engl J Med 2017;377:2545-2554.

33. Locke FL, Neelapu SS, Bartlett NL, Siddiqi T, Chavez JC, Hosing CM, Ghobadi $A$, Budde $L E$, Bot $A$, Rossi JM, Jiang $Y$, Xue AX, Elias M, Aycock J, Wiezorek J, Go WY. Phase 1 results of ZUMA-1: a multicenter study of KTE-C19 anti-CD19 CAR T cell therapy in refractory aggressive lymphoma. Mol Ther 2017;25:285-295.

34. Neelapu SS, Locke FL, Bartlett NL, Lekakis $\sqcup$, Miklos DB, Jacobson CA, Braunschweig I, Oluwole 00, Siddiqi T, Lin Y, Timmerman JM, Stiff PJ, Friedberg JW, Flinn IW, Goy A, Hill BT, Smith MR, Deol A, Farooq U, McSweeney P, Munoz J, Avivi I, Castro JE, Westin JR, Chavez JC, Ghobadi $A$, Komanduri KV, Levy $R$, Jacobsen ED, Witzig TE, Reagan $P$, Bot $A$, Rossi J, Navale L, Jiang Y, Aycock J, Elias M, Chang D, Wiezorek J, Go WY. Axicabtagene ciloleucel CAR T-cell therapy in refractory large B-cell lymphoma. N Engl J Med 2017;377:2531-2544.

35. U.S. Food \& Drug Administration. News Release. FDA Approves CAR-T Cell Therapy to Treat Adults with Certain Types of Large B-Cell Lymphoma. Washington, FDA, 2017.

36. Ramos $C A$, Ballard $B$, Zhang $H$, Dakhova 0 , Gee AP, Mei Z, Bilgi M, Wu MF, Liu H, Grilley B, Bollard CM, Chang BH, Rooney CM, Brenner MK, Heslop $H E$, Dotti G, Savoldo B. Clinical and immunological responses after CD30specific chimeric antigen receptor-redirected lymphocytes. J Clin Invest 2017;127:3462-3471.

37. Tai YT, Anderson KC. Targeting B-cell maturation antigen in multiple myeloma. Immunotherapy 2015;7:1187-1199.

38. Carpenter RO, Evbuomwan MO, Pittaluga S, Rose JJ, Raffeld M, Yang S, Gress $\mathrm{RE}$, Hakim F, Kochenderfer JN. B-cell maturation antigen is a promising target for adoptive T-cell therapy of multiple myeloma. Clin Cancer Res 2013;19:2048-2060.

39. Berdeja JG, Lin Y, Raje N, Munshi N, Siegel D, Liedtke M, Jagannath S, Maus MV, Turka A, Lam LP, Hege K, Morgan RA, Quigley MT, Kochenderfer JN. Durable clinical responses in heavily pretreated patients with relapsed/ refractory multiple myeloma: updated results from a multicenter study of bb2121 anti-Bcma CAR T cell therapy. Blood 2017;130:740.
40. Cohen AD, Garfall AL, Stadtmauer EA, Lacey SF, Lancaster E, Vogl DT, Weiss BM, Ambrose DE, Nelson AM, Chen F, Plesa G, Kulikovskaya I, Gonzalez V, Gupta M, Young RM, Dengel K, O'Keefe L, Le S, Richardson C, Isaacs RE, Melenhorst JJ, Levine BL, June $\mathrm{CH}$, Milone MC. Safety and efficacy of B-cell maturation antigen (BCMA)-specific chimeric antigen receptor $\mathrm{T}$ cells (CART-BCMA) with cyclophosphamide conditioning for refractory multiple myeloma (MM). Blood 2017;130(Suppl 1):505.

41. Smith EL, Staehr M, Masakayan R, Tatake IJ, Purdon TJ, Wang X, Wang P, Liu H, Xu Y, Garrett-Thomson SC, Almo SC, Riviere I, Liu C, Brentjens RJ. Development and evaluation of an optimal human single-chain variable fragment-derived BCMA-targeted CAR T cell vector. Mol Ther 2018;26:1447-1456.

42. Friedman KM, Garrett TE, Evans JW, Horton HM, Latimer HJ, Seidel SL, Horvath CJ, Morgan RA. Effective targeting of multiple B-cell maturation antigen-expressing hematological malignances by anti-B-cell maturation antigen chimeric antigen receptor T cells. Hum Gene Ther 2018;29:585-601.

43. Lee L, Draper B, Chaplin N, Philip B, Chin M, Galas-Filipowicz D, Onuoha S, Thomas S, Baldan V, Bughda R, Maciocia P, Kokalaki E, Neves MP, Patel D, Rodriguez-Justo M, Francis J, Yong K, Pule M. An APRIL-based chimeric antigen receptor for dual targeting of $\mathrm{BCMA}$ and $\mathrm{TACl}$ in multiple myeloma. Blood 2018;131:746-758.

44. Watanabe $K$, Terakura $S$, Martens $A C$, van Meerten $T$, Uchiyama $S$, Imai $M$, Sakemura R, Goto T, Hanajiri R, Imahashi N, Shimada K, Tomita A, Kiyoi H, Nishida T, Naoe T, Murata M. Target antigen density governs the efficacy of anti-CD20-CD28-CD3 zeta chimeric antigen receptor-modified effector CD8+ T cells. J Immunol 2015;194:911-920.

45. Lim WA, June $\mathrm{CH}$. The principles of engineering immune cells to treat cancer. Cell 2017;168:724-740.

46. Hombach AA, Heiders J, Foppe $M$, Chmielewski M, Abken H. OX40 costimulation by a chimeric antigen receptor abrogates CD28 and IL-2 induced IL-10 secretion by redirected CD4+ T cells. Oncoimmunology 2012;1:458-466.

47. Cherkassky L, Morello A, Villena-Vargas J, Feng Y, Dimitrov DS, Jones DR, Sadelain M, Adusumilli PS. Human CAR T cells with cell-intrinsic PD-1 checkpoint blockade resist tumor-mediated inhibition. J Clin Invest 2016;126:3130-3144.

48. Ajina A, Maher J. Prospects for combined use of oncolytic viruses and CAR T-cells. J Immunother Cancer 2017;5:90.

49. Pule MA, Savoldo B, Myers GD, Rossig C, Russell HV, Dotti G, Huls MH, Liu E, Gee AP, Mei Z, Yvon E, Weiss HL, Liu H, Rooney CM, Heslop HE, Brenner MK. Virus-specific T cells engineered to coexpress tumor-specific receptors: persistence and antitumor activity in individuals with neuroblastoma. Nat Med 2008;14:1264-1270.

50. Chmielewski M, Hombach AA, Abken H. Of CARs and TRUCKs: chimeric antigen receptor (CAR) T cells engineered with an inducible cytokine to modulate the tumor stroma. Immunol Rev 2014;257:83-90.

51. Scarfo I, Maus MV. Current approaches to increase CAR T cell potency in solid tumors: targeting the tumor microenvironment. J Immunother Cancer 2017;5:28.

52. Ren J, Zhao Y. Advancing chimeric antigen receptor T cell therapy with CRISPR/Cas9. Protein Cell 2017;8:634-643.

53. Sadelain M, Brentjens R, Riviere I. The basic principles of chimeric antigen receptor design. Cancer Discov 2013;3:388-398.

54. Straathof KC, Pulè MA, Yotnda P, Dotti G, Vanin EF, Brenner MK, Heslop HE, Spencer DM, Rooney CM. An inducible caspase 9 safety switch for T-cell therapy. Blood 2005;105:4247-4254.

55. Boissel L, Betancur M, Wels WS, Tuncer H, Klingemann H. Transfection with mRNA for CD19 specific chimeric antigen receptor restores NK cell mediated killing of CLL cells. Leuk Res 2009;33:1255-1259.

56. Beatty $G L$, Haas AR, Maus MV, Torigian DA, Soulen MC, Plesa G, Chew A, Zhao Y, Levine BL, Albelda SM, Kalos M, June CH. Mesothelin-specific 
chimeric antigen receptor mRNA-engineered T cells induce anti-tumor activity in solid malignancies. Cancer Immunol Res 2014;2:112-120.

57. Doronin II, Vishnyakova PA, Kholodenko IV, Ponomarev ED, Ryazantsev DY, Molotkovskaya IM, Kholodenko RV. Ganglioside GD2 in reception and transduction of cell death signal in tumor cells. BMC Cancer 2014;14:295.

58. Morgan RA, Yang JC, Kitano M, Dudley ME, Laurencot CM, Rosenberg SA. Case report of a serious adverse event following the administration of $\mathrm{T}$ cells transduced with a chimeric antigen receptor recognizing ERBB2. Mol Ther 2010;18:843-851.

59. Ahmed N, Brawley V, Hegde M, Bielamowicz K, Kalra M, Landi D, Robertson C, Gray TL, Diouf O, Wakefield A, Ghazi A, Gerken C, Yi Z, Ashoori A, Wu MF, Liu H, Rooney C, Dotti G, Gee A, Su J, Kew Y, Baskin D, Zhang YJ, New P, Grilley B, Stojakovic M, Hicks J, Powell SZ, Brenner MK, Heslop HE, Grossman R, Wels WS, Gottschalk S. HER2-Specific chimeric antigen receptor-modified virus-specific T cells for progressive glioblastoma: a phase 1 dose-escalation trial. JAMA Oncol 2017;3:1094-1101.

60. Jain $M$, Zhang L, He M, Patterson EE, Nilubol N, Fojo AT, Joshi B, Puri R, Kebebew E. Interleukin-13 receptor alpha2 is a novel therapeutic target for human adrenocortical carcinoma. Cancer 2012;118:5698-5708.

61. Fichtner-Feigl S, Strober W, Kawakami K, Puri RK, Kitani A. IL-13 signaling through the IL-13 $\alpha 2$ receptor is involved in induction of TGF- $\beta 1$ production and fibrosis. Nat Med 2006;12:99-106.

62. Bagley SJ, Desai AS, Linette GP, June CH, O'Rourke DM. CAR T cell therapy for glioblastoma: recent clinical advances and future challenges. Neuro Oncol 2018.

63. Brown $C E$, Badie $B$, Barish ME, Weng L, Ostberg JR, Chang WC, Naranjo A, Starr R, Wagner J, Wright C, Zhai Y, Bading JR, Ressler JA, Portnow J, D'Apuzzo M, Forman SJ, Jensen MC. Bioactivity and safety of IL13R $\alpha 2-$ redirected chimeric antigen receptor CD8+ T cells in patients with recurrent glioblastoma. Clin Cancer Res 2015;21:4062-4072.

64. Brown $C E$, Alizadeh $D$, Starr $R$, Weng $L$, Wagner JR, Naranjo A, Ostberg $J R$, Blanchard MS, Kilpatrick J, Simpson J, Kurien A, Priceman SJ, Wang X, Harshbarger TL, D'Apuzzo M, Ressler JA, Jensen MC, Barish ME, Chen M, Portnow J, Forman SJ, Badie B. Regression of glioblastoma after chimeric antigen receptor T-cell therapy. N Engl J Med 2016;375:2561-2569.

65. Gan HK, Cvrljevic AN, Johns TG. The epidermal growth factor receptor variant III (EGFRvIII): where wild things are altered. FEBS J 2013;280:53505370 .
66. Johnson LA, Scholler J, Ohkuri T, Kosaka A, Patel PR, McGettigan SE, Nace AK, Dentchev T, Thekkat P, Loew A, Boesteanu AC, Cogdill AP, Chen T, Fraietta $J A$, Kloss CC, Posey AD Jr, Engels B, Singh R, Ezell $T$, Idamakanti $N$, Ramones MH, Li N, Zhou L, Plesa G, Seykora JT, Okada H, June CH, Brogdon JL, Maus MV. Rational development and characterization of humanized anti-EGFR variant III chimeric antigen receptor T cells for glioblastoma. Sci Transl Med $2015 ; 7: 275$ ra22.

67. O'Rourke DM, Nasrallah MP, Desai A, Melenhorst JJ, Mansfield K, Morrissette JJD, Martinez-Lage M, Brem S, Maloney E, Shen A, Isaacs R, Mohan S, Plesa G, Lacey SF, Navenot JM, Zheng Z, Levine BL, Okada H, June CH, Brogdon $J L$, Maus MV. A single dose of peripherally infused EGFRvIll-directed CAR T cells mediates antigen loss and induces adaptive resistance in patients with recurrent glioblastoma. Sci Transl Med 2017;9:0984.

68. Wang OS, Wang Y, Lv HY, Han QW, Fan H, Guo B, Wang LL, Han WD. Treatment of CD33-directed chimeric antigen receptor-modified T cells in one patient with relapsed and refractory acute myeloid leukemia. Mol Ther 2015;23:184-191.

69. Wang CM, Wu ZQ, Wang Y, Guo YL, Dai HR, Wang XH, Li X, Zhang YJ, Zhang WY, Chen MX, Zhang Y, Feng KC, Liu Y, Li SX, Yang OM, Han WD. Autologous $T$ cells expressing CD30 chimeric antigen receptors for relapsed or refractory Hodgkin lymphoma: an open-label phase I trial. Clin Cancer Res 2017;23:1156-1166.

70. Wang OS, Wang Y, Lv HY, Han OW, Fan H, Guo B, Wang LL, Han WD. Treatment of CD33-directed chimeric antigen receptor-modified $T$ cells in one patient with relapsed and refractory acute myeloid leukemia. Mol Ther 2015;23:184-191.

71. Zhang WY, Wang Y, Guo YL, Dai HR, Yang QM, Zhang YJ, Zhang Y, Chen MX, Wang CM, Feng KC, Li SX, Liu Y, Shi FX, Luo C, Han WD. Treatment of CD20-directed chimeric antigen receptor-modified $\mathrm{T}$ cells in patients with relapsed or refractory B-cell non-Hodgkin lymphoma: an early phase Ila trial report. Signal Transduct Target Ther 2016;1:16002.

72. Ritchie DS, Neeson PJ, Khot A, Peinert $S$, Tai T, Tainton $K_{1}$ Chen $K$, Shin M, Wall DM, Hönemann D, Gambell P, Westerman DA, Haurat J, Westwood JA, Scott AM, Kravets L, Dickinson M, Trapani JA, Smyth MJ, Darcy PK, Kershaw MH, Prince HM. Persistence and efficacy of second generation CAR T cell against the LeY antigen in acute myeloid leukemia. Mol Ther 2013;21:2122-2129.

73. Till BG, Jensen MC, Wang J, Qian $X$, Gopal AK, Maloney DG, Lindgren CG, Lin Y, Pagel JM, Budde LE, Raubitschek A, Forman SJ, Greenberg PD, Riddell SR, Press OW. CD20-specific adoptive immunotherapy for lymphoma using a chimeric antigen receptor with both $C D 28$ and 4-1BB domains: pilot clinical trial results. Blood 2012;119:3940-3950. 